\title{
Penerapan Metode SQ3R dalam Meningkatkan Hasil Belajar Biologi
}

\author{
Tri Sari Wijayanti \\ SMAN 1 Labuapi Lombok Barat \\ Email : trisariwijayanti@yahoo.co.id
}

\begin{abstract}
Abstrak. Penelitian ini bertujuan untuk mencari apakah SQ3R dapat meningatkan hasil belajar biologi siswa SMA Negeri 1 Labuapi pada materi pokok sistem pencernaan makanan. Penelitian ini adalah Penelitian Tindakan Kelas. Subyek kelas XI IPA 1 yang terdiri dari 33 siswa. Instrumen adalah dokumentasi, wawancara, tes, dan lembar observasi. Analisa data menunjukkan bahwa nilai rata-rata pada siklus I adalah 66,25 dan siklus II adalah 76,72. Hal itu berarti terdapat peningatan antara siklus I dan siklus II. Jadi, peneliti menyimpulkan bahwa metode SQ3R adalah sebuah metode yang bagus untuk diterapkan pada pembelajaran biologi.
\end{abstract}

\section{Kata kunci: Metode SQ3R dan Hasil Belajar Biologi}

Abstract. This research aimed to find out whether $S Q 3 R$ could enhance students' biology achievement at SMAN 1 Labuapi on food digestion system. This research was Classroom Action Research. Subject was XI IPA 1 which consisted of 33 students. Instrument was documentation, interview, test, and observation sheet. The data anlysis showed that means score of cycle I was 66,25 and cycle II was 76,72. It means that there is improved between cycle I and cycle II. So, the reseracher conclude that SQ3R method is a good method to be applied in learning biology.

\section{Kata kunci: Metode SQ3R dan Hasil Belajar Biologi}

\section{PENDAHULUAN}

Belajar merupakan tindakan dan perilaku peserta didik yang komplek. Sebagai tindakan, maka belajar hanya dialami peserta didik itu sendiri. Peserta didik adalah penentu terjadi atau tidaknya proses belajar. Proses belajar terjadi berkat peserta didik memperoleh sesuatu yang ada di lingkungan sekitar, yang berupa alam, benda-benda, hewan, tumbuh-tumbuhan, manusia maupun hal-hal yang dijadikan bahan belajar. Selain itu perlu adanya intreraksi antara guru dan peserta didik. Sedangkan interaksi terjadi saat guru mengajar di kelas. Dimyati dan Mudjiono menyatakan bahwa dalam teori kognitif belajar menunjukkan adanya jiwa yang aktif, jiwa mengolah informasi yang kita terima, tidak sekedar menyimpannya saja tanpa mengadakan transformasi (Sutarto, 2017). Hal ini sesuai dengan salah satu prinsip belajar adalah keaktifan. Dengan demikian, belajar hanya dapat terjadi apabila peserta didik aktif mengalami sendiri. Dalam mewujudkan peserta didik aktif maka perlu adanya aktivitas belajar. Aktivitas belajar ini dapat terwujud jika peserta didik dihadapkan pada masalah.

Berhasil atau gagalnya pencapaian tujuan pendidikan tergantung pada proses belajar mengajar yang dialami peserta didik dan guru. Hilgard dan Marquis berpendapat bahwa belajar merupakan proses mencari ilmu yang terjadi dalam diri seseorang melalui latihan dan pembelajaran sehingga terjadi perubahan dalam diri sendiri (Sagala, 2013). Untuk itu guru perlu meningkatkan mutu pembelajarannya, dimulai rancangan pembelajaran yang baik dengan memperhatikan tujuan, karakteristik peserta didik, materi yang diajarkan, dan sumber belajar yang tersedia. Kenyataannya masih banyak ditemui proses pembelajaran yang kurang berkualitas, tidak efisien dan kurang mempunyai daya tarik, bahkan cenderung membosankan, sehingga hasil belajar yang dicapai tidak optimal.

Proses pembelajaran yang baik adalah pengajaran yang menyediakan dan memberi 
kesempatan pada peserta didik untuk mengembangkan otak kiri (otak perekam) dan otak kanan (otak pemikir). Peserta didik tidak hanya tahu tentang "sesuatu" tetapi juga dapat bertanya tentang sesuatu, dapat menyampaikan sesuatu, dan dapat memperagakan sesuatu (Harsanto, 2007). Salah satu proses pembelajaran dengan menggunakan otak kanan/otak berfikir adalah mengkritisi apa yang dibaca serta mampu menerangkan apa yang dibaca kepada orang lain dengan katakatanya sendiri.

Kerja sama dalam kelompok dapat dikaitkan dengan nilai, sehingga kerja sama peserta didik makin intensif dan peserta didik dapat mencapai kompetensinya. Belajar bersama dalam kelompok adalah suatu cara yang dipakai untuk menyelenggarakan pembelajaran dalam bentuk kelompok belajar yang lebih kecil. Paserta didik dalam satu kelas dibagi menjadi beberapa kelompok belajar yang lebih kecil yang heterogen (campuran) dalam hal kemampuan intelektual, jenis kelamin, dan latar belakang budaya, sehingga terwujud kerjasama untuk saling membantu dalam memahami materi. Dipandang dari tingkat partisipasi aktif peserta didik, keuntungan belajar bersama secara kelompok mempunyai tingkat partisipasi aktif yang tinggi. Supaya memperoleh hasil belajar yang berkualitas, harus dirancang proses pembelajaran yang berkualitas dengan memperhatikan tingkat berpikir yang akan dipelajari dan dilatihkan. Rancangan proses pembelajaran yang baik adalah rancangan pembelajaran yang menggunakan indikator belajar sebagai rambu-rambu dalam pencapaian hasil. Indikator yang dirumuskan sacara baik dapat digunakan untuk mendeteksi sejauh mana hasil belajar dapat dicapai. Mengalami langsung apa yang sedang dipelajari akan mengaktifkan lebih banyak indera daripada hanya mendengarkan guru menerangkan. Hal ini menunjukkan bahwa jika mengajar dengan banyak berceramah, maka tingkat pemahaman peserta didik hanya $20 \%$, tetapi jika peserta didik diminta untuk melakukan sesuatu sambil mengkomunikasikan, tingkat pemahaman peserta didik dapat mencapai sekitar $90 \%$.
Pada dasarnya semua anak memiliki potensi untuk mencapai kompetensi sehingga perlu adanya kreatifitas guru untuk membantu mencapainya.

Untuk itu penulis menerapkan metode pembelajaran SQ3R. Metode belajar tersebut adalah cara mempelajari teks (bacaan) khususnya yang terdapat dalam buku, artikel ilmiah, dan laporan penelitian. Peserta didik akan mudah mengingat materi, karena peserta didik belajar secara berkelompok dan diberi kesempatan lebih aktif mencari serta memahami materi dari teks atau buku sehingga terdapat peluang lebih besar untuk meningkatkan hasil belajar biologi pada materi pokok sistem pencernaan makanan.

Menurut Islamuddin (2010: 179-181) langkah-langkah metode SQ3R secara lengkap dijelaskan sebagai berikut ini :

1. Survey: Dalam melakukan aktivitas survei, membantu dan mendorong siswa untuk memeriksa atau meneliti secara singkat seluruh struktur teks. Judul bagian (heading) dan judul subbagian (subheading), Istilah dan kata kunci, dan sebagainya. Dalam melakukan survei, siswa dianjurkan menyiapkan pensil, kertas, dan alat pebuat ciri (berwarna kuning, hijau dan sebagainya) seperti stabilo untuk menandai bagian-bagian tertentu. Bagian-bagian penting dan akan dijadikan bahan pertanyaan, perlu ditandai untuk memudahkan proses penyusunan daftar pertanyaan pada langkah selanjutnya.

2. Question : Memberi petunjuk atau contoh kepada para siswa untuk menyusun pertanyaan-pertanyaan yang jelas, singkat, dan relevan dengan bagian-bagian teks yang telah ditandai pada langkah pertama.jumlah pertanyaan tergantung pada panjang pendeknya teks, dan kemampuan siswa dalam memahami teks yang sedang dipelajari. Jika teks yang sedang dipelajari siswa berisi hal-hal yang sebelumnya sudah diketahui, mungkin mereka hanya perlu membuat beberapa pertanyaan. Sebaliknya, apabila latar belakang pengetahuan siswa tidak berhubungan dengan ini teks, maka ia 
perlu menyusun pertanyaan sebanyakbanyanya.

3. Read: Siswa membaca secara aktif dalam rangka mencari jawaban atas pertanyaanpertanyaan yang telah tersusun. Dalam hal ini, membaca secara aktif juga berarti membaca yang difokuskan pada paragrafparagraf yang diperkirakan mengandung jawaban-jawan yang diperkirakan relevan dengan pertanyaan tadi.

4. Recite : Menyebut lagi jawaban-jawaban atas pertanyan-pertanyan yang telah tersusun. Latihlah siswa untuk tidak membuka catatan jawaban. Jika jika sebuah pertanyan tidaksiswa tetap disuruh menjawab pertanyaan berikutnya. Dengan seterusnya, hingga seluruh pertanyaan, termasuk yangbelum terjawab, dapat diselsaikan dengan baik.

5. Review : Pada langkah teakhir (review) siswa untuk meninjau ulang seluruh pertanyaan dan jawaban secara singkat.

\section{METODE PENELITIAN}

Metode penelitian yang penulis gunakan dalam penelitian ini adalah Penelitian Tindakan Kelas (PTK). Penelitian Tindakan Kelas adalah suatu penelitian yang dilakukan oleh guru dikelasnya sendiri melalui refleksi diri dengan tujuan untuk memperbaiki kinerjanya sehingga hasil belajar peserta didik meningkat. Penelitian tindakan ini dilaksanakan selama dua siklus yaitu siklus I dan siklus II.

Model penelitian tindakan yang dilakukan dalam penelitian ini adalah model spiral dari Kemmis dan Taggart yang terdiri dari beberapa siklus tindakan. Dimana setiap siklus tersebut terdiri 4 tahapan yang meliputi perencanaan pelaksanaan tindakan, observasi dan refleksi.

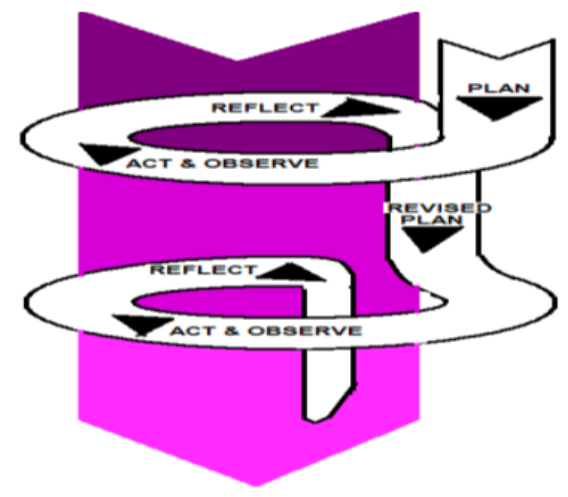

Gambar 1. Model spiral dari Kemmis dan Taggart

\section{HASIL DAN PEMBAHASAN Hasil}

Dalam siklus I juga masih banyak terdapat peserta didik yang bergantung dengan teman satu kelompoknya untuk menyelesaikan tugas atau dapat dikatakan rasa tanggung jawab diri sendiri masih kurang. Terbukti dalam diskusi kelompok kecil maupun presentasi kelompok di depan kelas masih didominasi satu, dua anak yang tergolong pandai sedangkan peserta didik yang lain terlihat lebih pasif. Bahkan dalam pertemuan pertama masih terdapat kegaduhan dari beberapa peserta didik sehingga waktu untuk diskusi kelompok kecil menjadi molor dari waktu yang ditentukan yaitu 1 kelompok 25 menit .

Dalam presentasi kelompok di depan kelas belum ada kerjasama antar anggota, pengelolaan waktu dari moderator juga belum ada, serta pembatasan masalah atau materi belum terlaksana sehingga presentasi melebar sampai membahas sekilas tentang organ pencernaan pada manusia. Kemudian guru mencoba menengahi dan memngembalikan pada pembahasan materi yaitu zat-zat makanan.

Hasil belajar siklus I terlihat dari nilai diskusi dan nilai evaluasi. Pada saat pelaksanaan pembelajaran mengunakan metode SQ3R sekaligus dilakukan penilaian diskusi oleh guru dan peneliti ada tiga peserta didik yang tidak hadir sehingga nilainya nol. Penilaian diskusi untuk kelompok berdasarkan penguasaan materi yang dipresentasikan, pengelolaan waktu dalam presentasi, pembuatan rangkuman materi sebagai bahan presentasi serta menjawab pertanyaan yang diajukan kelompok lain. Sedangkan penilaian 
individu berdasarkan keaktifan dalam proses pembelajaran, kerjasama dalam satu kelompok. Berdasarkan nilai diskusi pada siklus I, peserta didik yang tidak tuntas ada 7 anak. Perolehan rata-rata hasil belajar sebesar 62,2 dengan ketuntasan belajar hanya mencapai $76,67 \%$.

Hasil belajar siklus II terlihat dari nilai diskusi dan nilai evaluasi. Pada saat pelaksanaan pembelajaran mengunakan metode SQ3R sekaligus penilaian diskusi berdasarkan nilai kelompok dan nilai individu. Penilaian diskusi untuk kelompok berdasarkan penguasaan materi yang dipresentasikan, pengelolaan waktu dalam presentasi, pembuatan rangkuman materi sebagai bahan presentasi serta menjawab pertanyaan yang diajukan kelompok lain, kerjasama dalam satu kelompok. Sedangkan penilaian individu berdasarkan keaktifan dalam proses pembelajaran baik mengajukan pertanyaan maupun membantu menjawab pertanyaan apabila presentator tidak mampu menjawab pertnyaan dari kelompok lain, kerjasama dalam satu kelompok. Berdasarkan nilai diskusi pada siklus II, peserta didik yang tidak tuntas ada 3 anak. Perolehan rata-rata hasil belajar sebesar 75,73 dengan ketuntasan belajar mencapai $90,9 \%$. Peserta didik yang < KKM dalam menyelesaikan soal evaluasi yaitu 2 anak. Dengan perolehan rata-rata hasil belajar sebesar 76,30 dengan ketuntasan belajar mencapai 93,93\%. Hasil ketuntasan belajar dapat dilihat pada diagram berikut ini:

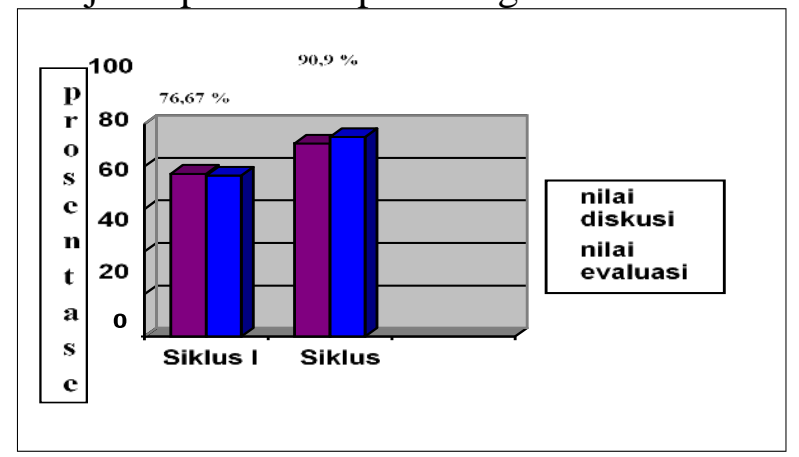

\section{Histogram 1. ketuntasan belajar dari nilai diskusi Peserta didik dan ketuntasan belajar dari nilai evaluasi peserta didik}

Selain peningkatan yang terjadi terhadap ketuntasan belajar dari nilai diskusi peserta didik dan ketuntasan belajar dari nilai evaluasi peserta didik, dalam penelitian ini juga terjadi peningkatan terhadap rata-rata hasil belajar peserta didik. Dengan bukti jika dalam siklus I nilai rata-rata kelas pada nilai diskusi 62,2 pada siklus II mengalami peningkatan yaitu 75,72. Sedangkan nilai rata-rata evaluasi siklus I 66,25 mengalami peningkatan menjadi 76,30. Dapat dituliskan dalam tabel sebagai berikut : Tabel 1. Nilai rata-rata siklus I dan siklus II

\begin{tabular}{|l|l|l|l|l}
\hline Rata-rata & Siklus I & Siklus II & Interval Nilai & Kriteria \\
\hline Nilai diskusi & 62,2 & 75,72 & $>3,6$ & Sangat Valid \\
\hline Nilai evaluasi & 66,25 & 76,72 & $2,8-3,6$ & Valid \\
\hline & & & $1,9-2,7$ & Tidak Valid \\
\hline & & & $1,0-1,8$ & Sangat Tidak V \\
\hline
\end{tabular}

Berdasarkan hasil penelitian siklus I kemudian dilakukan refleksi terhadap langkahlangkah yang telah diaksanakan. Hasil refleksi tersebut adalah pada pelaksanaan siklus II yang dipandang sudah cukup dalam meningkatkan baik semangat peserta didik, aktivitas belajar maupun hasil belajar peserta didik pada penerapan "Metode pembelajaran SQ3R dalam materi sistem pencernaan makanan pada manusia untuk meningkatkan hasil belajar peserta didik kelas XI IPA 1 di SMA Negeri 1 Labuapi sudah mencapai indikator keberhasilan yang ditetapkan".

\section{Pembahasan}

Penelitian ini bertujuan untuk mencari apakah metode SQ3R dapat meningkatkan hasil belajar biologi siswa SMA Negeri 1 Labuapi pada materi pokok sistem pencernaan makanan. Dari pengamatan siklus I diperoleh temuan antara lain guru dalam melaksanakan penerapan "Metode pembelajaran SQ3R" diawali dengan tahap pemberian apersepsi terhadap materi di kelas dengan metode konvensional, kemudian membagi kelompok dan selanjutnya pesera didik melaksanakan proses pembelajaran mengunakan metode SQ3R akan tetapi pengelolaan waktu kegiatan pembelajaran kurang baik terlihat molornya waktu diskusi kelompok kecil sehingga waktu presentasi singkat. Selain itu juga dalam memberikan motivasi dan bimbingan terhadap peserta didik baik dalam kelompok maupun individu kurang merata sehingga ada beberapa peserta didik yang merasa kesulitan dalam menyelesaikan pemecahan soal diskusi yang diberikan. 
Berdasarkan refleksi pada siklus I, pelaksanaan tindakan pada siklus II oleh guru sudah baik dengan bukti pengelolaan waktu yang sudah sesuai dengan rencana pembelajaran dan pemberian semangat oleh guru kepada peserta didik sudah merata. Disamping itu, peserta didik juga sudah mampu melaksanakan tahapan-tahapan "Metode pembelajaran SQ3R" dengan baik. Terbukti dengan adanya pencarian referensi yang dilakukan peserta didik, diskusi kelompok kecil yang berjalan lancar, presentasi yang cukup memuaskan serta mampu menyelesaikan soal evaluasi

Hasil penelitian ini juga pernah dilakukan oleh Siti Gunarti (2010) dengan judul Implementasi Metode Pembelajaran SQ3R (Survey, Question, Read, Recite, Review) dalam Upaya Meningkatkan Hasil Belajar Biologi Materi Pokok Sistem Pencernaan Makanan Kelas XI SMA YATPI (Yayasan Taman Pendidikan Islamiyah) Godong-Grobogan. Permasalahan yang akan dibahas dalam penelitian ini yaitu: 1)Apakah implemtasi metode pembelajaran SQ3R dapat meningkatkan hasil belajar biologi di SMA YATPI Godong-Grobogan? 2) Apa yang menjadi hambatan implementasi metode pembelajaran SQ3R terhadap hasil belajar biologi di SMA YATPI GodongGrobogan? Penelitian ini bertujuan: 1) Untuk mengetahui implementasi metode pembelajaran SQ3R terhadap hasil belajar biologi peserta didik kelas XI di SMA YATPI Godong-Grobogan. 2) Untuk mengetahui hambatan implementasi metode pembelajaran SQ3R terhadap hasil biologi di SMA YATPI Godong-Grobogan. Penelitian ini merupakan penelitian tindakan kelas (Classroom Action Research) yang dilaksanakan dalam 2 siklus. Subyek penelitian adalah siswa kelas XI SMA YATPI Godong-Grobogan pada semester genap tahun pelajaran 2009-2010 dengan jumlah peserta didik sebanyak 33 orang. Prosedur penelitian terdiri dari 4 tahap di setiap siklusnya, yakni perencanaan, pelaksanaan tindakan, observasi dan refleksi. Proses pembelajaran biologi dilaksanakan dengan menggunakan metode pembelajaran SQ3R. Indikator hasil belajar pada penelitian ini berupa tercapainya ketuntasan belajar secara individual maupun klasikal. Pengumpulan datanya dilakukan dengan metode: wawancara, observasi, dokumentasi, diskusi dan tes evaluasi. Data hasil pengamatan nilai diskusi dan nilai evaluasi diolah dengan analisis deskriptif untuk menggambarkan keadaan peningkatan pencapaian keberhasilan tiap siklus. Hasil penelitian menunjukkan bahwa: 1) Hasil belajar biologi siswa melalui penerapan metode pembelajaran SQ3R mengalami peningkatan, khususnya pada materi pokok sistem pencernaan makanan. Pada siklus I diperoleh nilai diskusi individu < KKM sebanyak 7 anak sedangkan > KKM 23 anak dengan rata-rata 62,2 dan ketuntasan belajar $76,67 \%$ meningkat menjadi 75,73 dengan ketuntasan belajar 90,9\% pada siklus II yaitu < KKM sebanyak 3 anak sedangkan > KKM 30 anak. Serta nilai evaluasi dengan rata-rata 66,25 dengan ketuntasan belajar 75,75\%

dan meningkat menjadi 76,30 dengan ketuntasan belajar 93,93\% pada siklus II. Sehingga bisa disimpulkan bahwa terjadi peningkatan nilai rata-rata dari siklus I ke siklus II dan tidak perlu dilakukan siklus ke III. 2) Hambatan pengunaan metode SQ3R yaitu sikap pasif peserta didik serta bergantung pada orang lain dalam proses pembelajaran dan keterbatasan fasilitas pembelajaran seperti sumber belajar dan alat peraga pembelajaran yang tersedia.

\section{KESIMPULAN}

Hasil belajar peserta didik dengan penerapan metode pembelajaran SQ3R (Survey, Question, Read, Recite, Review) khususnya pada materi pokok sistem pencernaan manusia mengalami peningkatan yaitu dari nilai diskusi siklus I dengan rata-rata 62,2 dengan ketuntasan belajar klasikal (seluruh peserta didik) 76,67\%, meningkat menjadi 75,73 dengan ketuntasan belajar klasikal (seluruh peserta didik) 90,9\% pada siklus II. Sedangkan nilai evaluasi dengan rata-rata 62,25 dengan ketuntasan belajar klasikal (seluruh peserta didik) 75,75\% meningkat menjadi 76,30 dengan ketuntasan 
belajar klasikal (seluruh peserta didik) 93,93\% . Maksudnya, pada siklus I, ada 7 peserta didik yang tidak tuntas dalam nilai diskusi serta 8 peserta didik yang memperoleh nilai evaluasi di bawah KKM (62), sedangkan pada siklus II, hanya ada 3 peserta didik tidak tuntas nilai diskusi dan 2 peserta didik yang nilai evaluasinya di bawah KKM.

Hambatan yang dialami dalam proses pembelajaran menggunakan metode pembelajaran SQ3R (Survey, Question, Read, Recite, Review) untuk meningkatkan hasil belajar pada materi sistem pencernaan makanan manusia antara lain : Motivasi dari peserta didik untuk belajar masih tergolong rendah apalagi ketika guru tidak mampu bersikap tegas dalam pembelajaran maupun pemberian nilai hal tersebut akan sedikit demi sedikit mengalami perubahan apabila mulai didukung dari berbagai pihak yaitu keluarga dan sekolah, adanya keterbatasan buku di sekolah, walaupun didukung referensi dari internet, tetapi tanpa adanya kreatifitas peserta didik untuk mencari sumber materi dari tempat lain, juga akan menjadi hambatan terlaksananya pembelajaran dengan metode SQ3R sehingga hasil belajar tidak mencapai indikator yaitu nilai 62 (sesuai KKM).

\section{SARAN}

Berdasarkan hasil pembahasan pada
bagian sebelumnya dalam upaya
meningkatkan hasil belajar, maka peneliti
merasa perlu memberikan saran-saran, antara lain : (a). Bagi sekolah, diharapkan sedikit demi sedikit dapat melengkapi sumber belajar (buku/alat peraga) sehingga peserta didik lebih termotivasi untuk meningkatkan prestasi dengan cara belajar dengan fasilitas yang ada. Atau dengan cara diharapkan kepada para pengajar atau pendidik untuk senantiasa memberikan suatu variasi dalam penyampaian materi pelajaran bagi peserta didik. Mampu memilih suatu metode pembelajaran yang sesuai dengan kebutuhan peserta didik, dan berkaitan dengan materi yang akan dibahas. Dengan harapan supaya peserta didik bisa lebih aktif mengikuti jalannya proses pembelajaran di kelas., (b). Bagi guru, sebaiknya guru selalu berusaha untuk membimbing kegiatan peserta didik dalam kerja kelompok. Bertujuan agar setiap peserta didik tidak saling menggantungkan diri dengan peserta didik yang lain dan benar-benar dapat bekerjasama dengan anggota kelompoknya. Sehingga ketika mengerjakan tugas dengan kerja kelompok ataupun sedang berdiskusi, setiap peserta didik turut aktif dan mengutarakan pendapat di dalam kelompok mereka., (c). Bagi peserta didik, sebaiknya ketika guru menerapkan suatu metode pembelajaran di kelas, mereka dapat mengikuti instruksi guru dengan baik agar hasil yang dicapai bisa sesuai dengan apa yang diharapkan oleh guru. Dengan begitu, akan tercipta kerjasama yang baik antara guru dan peserta didik selama proses pembelajaran berlangsung.

\section{UCAPAN TERIMA KASIH}

Dengan terselesaikannya penulisan penelitian tindakan kelas ini, peneliti tidak lupa mengucapkan puji syukur Alhamdulillah kehadirat Allah SWT atas Rahmat, Taufiq dan Hidayah-Nya.

Peneliti menyadari adanya kekurangan dan kelemahan yang ada dalam penelitian ini, oleh karena itu saran dan kritik yang membangun dari berbagai pihak tetap peneliti harapkan. Semoga tulisan ini bisa bermanfaat bagi peneliti pada khususnya dan pembaca pada umumnya.

Akhirnya tidak lupa peneliti sampaikan terima kasih kepada semua pihak yang telah membantu sepenuhnya dalam menyelesaikan penulisan artikel ini, semoga amal ibadahnya diterima oleh Allah SWT. Amien.

\section{DAFTAR PUSTAKA}

Dimyati \& Mudjiono. (2006). Belajar dan Pembelajaran. Jakarta: Rineka Cipta.

Djamarah, Zain. (2006). Strategi Belajar Mengajar. Jakarta: Rineka Cipta.

Harsanto, ratno. (2007). Pengelolaan Kelas yang Dinamis. Yogyakarta: Kanisius

Irianto, Kus. (2004). Struktur dan Fungsi Tubuh Manusia untuk Paramedis. Bandung: Yrama Widya.

Kurniasari, Nita. (2007). Penggunaan Metode Survet, Question, Read, Recite, 
Review (SQ3R) dalam Pembelajaran Kooperatif untuk Meningkatkan Hasil Belajar Ekonomi Pokok Bahasan Sistem Perekonomian Indonesia pada Peserta Didik Kelas VIII SMP NU 01 Muallimin Weleri Tahun Pelajaran 2006/2007. Skripsi Fakultas MIPA Universitas Negeri Semarang

Mawaria.(2018). Implementasi Metode SQ3R dalam Upaya Peningkatan Kemampuan Membaca Pemahaman Pada Mata Pelajaran Bahasa Indonesia Siswa SDN 135 Rejang Lebong. Ar-Riayah Jurnal Pendidikan Dasar STAIN Bengkulu, 2(2). $\quad$ DOI: http://dx.doi.org/10.29240/jpd.v2i2.6 $\underline{63}$

Mushobikhatun.(2018). Keefektifan Metode SQ3R pada Pembelajaran Konsep Sistem Ekskresi di Madrasah Aliyah Al Asror Gunungpati Semarang. Tulisan Fakultas MIPA Universitas Negeri Semarang

Sagala, Syaiful. (2013). Konsep dan Makna Pembelajaran. Bandung: CV Alfabeta.

Sutarto. (2017). Teori Kognitif dan Implikasinya dalam Pembelajaran. Islamic Counseling: Bimbingan dan Konseling Islam, STAIN Bengkulu 1 (2) 